\title{
PELAKSANAAN PERKAWINAN DI BAWAH UMUR PASCA PUTUSAN MAHKAMAH KONSTITUSI TAHUN 2018 DI KECAMATAN LENGKONG
}

\author{
oleh \\ Eni Dasuki Suhardini
}

\begin{abstract}
ABSTRAK
Pasal 7 ayat (1) Undang Undang Nomor 1 Tahun 1974 tentang Perkawinan mengatur batas minimal usia perkawinan yaitu laki laki (19 tahun), perempuan (16 tahun). Terhadap ketentan tsb Mahkamah Konstitusi menyatakan bertentangan dengan UUD 1945, UU No 35 Tahun 2014 tentang Perubahan atas UU No. 23 Tahun 2002 tentang Perlindungn Anak. Sekalipun telah ada pengaturan batas usia perkawinan, namun dalam pelaksanaannya masih terjadi perkawinan bawah umur . Bahkan Indonesia menduduki ranking 7 (dunia) dan ranking 2 (Asean). Perkawinan bawah umur disebabkan faktor ekonomi, Pendidikan, budaya dan agama. Upaya yang telah dilakukan oleh Pemerintah dalam menangani perkawinan bawah umur dengan melaksanakan penyuluhan program Genre Ceria , yang bertujuan agar generasi muda Indonesia terhindar dari kegiatan - kegiatan negatif, seperti penyalahgunaan narkoba, dan mendorong pelaksanaan wajib belajar 12 tahun.
\end{abstract}

Keyword: Perkawinan bawah umur ; Mahkamah Konstitusi ; Genre Ceria.

\section{PENDAHULUAN}

\section{Latar Belakang}

Mahkamah konstitusi pada kamis 13 Desember 2018 telah mengabulkan sebagian gugatan uji materi UU No.1/1474 tentang perkawinan yang mengatur tentang batas usia perkawinan anak. Dalam pertimbangan putusan disebutkan bahwa perbedaan batas usia perkawinan antara laki- laki dan perempuan bisa menimbulkan diskriminasi.

Pasal 7 ayat (1) UU Perkawinan mengatur batas minimal perkawinan laki- laki adalah 19 tahun sementara perempuan adalah 16 tahun, menurut Mahkamah Konstitusi ketentuan tersebut bertentangan dengan UUD 1945, yaitu :

Pasal 28 A : Setiap orang berhak untuk hidup serta berhak mempertahankan hidup dan kehidupannya

Pasal 28 B :ayat (1): Setiap orang berhak membentuk keluarga dan melanjutkan keturunan melalui perkawinan yang sah

ayat (2) Setiap anak berhak atas kelangsungan hidup, tumbuh, dan berkembang, serta berhak atas perlindungan dari kekerasan dan diskriminasi

Pasal 28 C ayat (2): Setiap orang berhak mengembangkan diri melalui pemenuhan kebutuhan dasarnya, berhak mendapat Pendidikan dan memperoleh manfaat dari ilmu pengetahuan dan teknologi,seni dan budaya, demi meningkatkan kualitas hidupnya dan demi kesejahteraan umat manusia

Pasal 28 D ayat (2): Setiap orang berhak atas pengakuan, jaminan, perlindungan dan kepastian hukum yang adil serta perlakuan yang sama di hadapan hukum

Pasal 28 G ayat (2): Setiap orang berhak atas perlindungan diri pribadi, keluarga, kehormatan, martabat dan harta benda yang di bawah kekuasaannya, serta berhak atas 
rasa aman dan perlindungan dari ancaman ketakutan untuk berbuat atau tidak berbuat sesuatu yang merupakan hak asasi

Pasal $28 \mathrm{H}$ ayat (1) : Setiap orang berhak hidup sejahtera lahir batin, bertempat tinggal, dan mendapatkan lingkungan hidup baik dan sehat, serta berhak memperoleh pelayanan kesehatan

ayat (2): Setiap orang mendapat kemudahan dan perlakuan khusus untuk memperoleh kesempatan dan manfaat yang sama guna mencapai persamaan dan keadilan

Pasal 28 I ayat (3) Hak untuk hidup, hak untuk tidak disiksa, hak kemerdekaan pikiran dan hati nurani, hak beragama, hak untuk tidak diperbudak, hak untuk diakui sebagai pribadi dihadapan hukum, dan hak untuk tidak dituntut atas dasar hukum yang berlaku surut adalah hak asasi manusia yang tidak dapat dikurangi dalam keadaan apa pun ayat (4) : Setiap orang berhak bebas atas perlakuan yang bersifat diskriminatif atas dasar apa pun dan berhak mendapatkan perlindungan terhadap perlakuan yang bersifat diskriminatif itu.

dan UU Perlindungan Anak. Undang- Undang Perlindungan Anak menyebutkan bahwa anak- anak adalah mereka yang berusia dibawah 18 tahun, sehingga batas usia yang diatur dalam UU Perkawinan masih kategori anak.

Pertimbangan lain dari Hakim MK, perkawinan anak dinilai sangat mengancam dan berdampak negatif terutama pada aspek kesehatan. Selain itu, peluang terjadinya eksploitasi dan ancaman kekerasan juga lebih tinggi pada anak. Aturan tersebut juga menimbulkan perbedaan perlakuan antara laki- laki dan perempuan.

Batas usia minimal 19 tahun yang dikategorikan bagi laki-laki dinilai memberikan rentang waktu yang lebih panjang sebagai anak dibandingkan perempuan. Selain itu perkawinan pada anak bedampak buruk terhadap Pendidikan anak. Pasal 31 UUD 1945 menyatakan bahwa " setiap warga negara berhak mendapatkan Pendidikan dasar 12 tahun". Sehingga apabila perempuan menikah pada usia 16 tahun, maka kehilangan hak Pendidikan dasar. Putusan MK tidak disertai dengan menentuakan batas usia perkawinan yang tepat bagi perempuan, karena hal ini merupsksn kewenangan Dewan Perwakilan Rakyat sebagai pembentuk Undang- Undang. Namun demikian MK meminta pembuat Undang- undang paling lama 3 (tiga) tahun untuk melakukan perubahan tentang perkawinan, khusunya berkenaan dengan batas usia minimal perempuan dalam perkawinan.

Permasalahan yang timbul dengan adanya putusan MK tersebut adalah mengapa MK menetapkan masa tunggu 3 tahun, karena seharusnya MK mampu melihat kedaruratan praktik perkawinan anak di Indonesia, berdasarkan data United Nations Children's Fund (UNICEF) sampai tahun 2017, Indonesia menduduki peringkat ke 7 angka perkawinan anak terbanyak di dunia dan posisi ke 2 di ASEAN.

Badan Pusat Statistik (BPS) menyebutkan pada tahun 2017, sebanyak 25\% (23 Provinsi dari 34 Provinsi) anak Indonesia sudah menikah, dan berdasarkan catatan di Pengadilan Agama Indramayu pada tahun 2017 terdapat 292 pengajuan dispensasi kawin, dan sebanyak 266 diputus majelis hakim. Pengajuan dispensasi kawin diperuntukan bagi yang ingin melangsungkan pernikahan, namun usianya masih dibawah ketentuan yang diatur dalam UU Perkawinan. 


\section{Perumusan Masalah}

1)Bagaimana pelaksanaan perkawinan di bawah umur pasca putusan Mahkamah Konstitusi di Kecamatan Lengkong Kota Bandung?

2) Apa yang menjadi faktor penyebab terjadinya perkawinan di bawah umur?

3) Upaya apa yang dilakukan oleh pemerintah dalam menangani perkawinan di bawah umur di Kecamatan Lengkong Kota Bandung ?

\section{TINJAUAN PUSTAKA}

Undang- undang Nomor 1 tahun 1974 tentang Perkawinan, menyatakan bahwa "Perkawinan adalah ikatan lahir batin antara seorang pria dengan seorang wanita sebagai suami istri dengan tujuan membentuk keluarga ( rumah tangga) yang bahagia dan kekal berdasrkan Ketuhanan Yang Maha Esa.

Perkawinan dalam ajaran Islam mempunyai nilai ibadah, sehingga dalam Pasal 2 Kompilasi Hukum Islam selanjutnya disebut KHI menegaskan bahwa perkawinan adalah akad yang sangat kuat untuk mentaati perintah Allah dan melaksanakannya merupakan ibadah. ${ }^{1}$

\section{Tinjauan Umum Tentang Perkawinan}

\subsubsection{Pengertian Perkawinan}

Perkawinan merupakan salah satu perbuatan hukum yang sudah melembaga dalam kehidupan masyarakat. Perkawinan merupakan faktor yang penting sebagai salah satu sendi kehidupan. Secara umum perkawinan berasal dari kata kawin, yang berarti perjodohan antara laki- laki dan wanita untuk menjadi suami isteri. Adapun perkawinan itu sendiri berarti pernikahan, atau perayaan dalam urusan kawin, dan sebagainya. Selain itu, ada juga yang mengartikannya dengan kumpul dan bercampur. ${ }^{2}$

Terdapat bermacam- macam pendapat yang dikemukakan orang mengenai pengertian perkawinan. Perbedaan antara pendapat- pendapat tersebut tidak memperlihatkan adanya pertentangan yang prinsip antara satu pendapat dengann pendapat lain, tetapi lebih memperlihatkan keinginan setiap perumus, mengenai banyaknya jumlah unsur- unsur yang hendak dimasukkan dalam perumusan pengertian perkawinan di satu pihak, sedangkan di pihak lain dibatasi pemasukan unsur- unsur di dalam perumusan pengertian perkawinan. ${ }^{3}$

Beberapa pendapat para ahli mengenai arti dari perkawinan yang dimaksud adalah sebagai berikut $:^{4}$

a. Barend Ter Haar, B.Z.n

Perkawinan adalah suatu usaha atau peristiwa hukum yang menyebabkan terus berlangsungnya golongan dengan tertibnya dan merupakan suatu syarat yang menyebabkan terlahirnya angkatan baru yang meneruskan golongan tersebut.

b. Djaen Saragih

Hukum perkawinan adat adalah keseluruhan kaidah hukum yang menetukan prosedur yang harus ditempuh oleh dua orang yang bertalian dalam menciptakan kehidupan bersama dalam suatu rumah tangga dengan tujuan untuk menerskan keturunan.

${ }^{1}$ Zainudin Ali, Hukum Perdata Islam di Indonesia, Jakarta, Sinar Grafika,2007, Hlm 7.

${ }^{2}$ Tihami dan Sohari Sahrani, Fiqh Munakahat: Kajian Fiqh Lengkap, Jakarta : Rajawali Press, 2009, Hlm 7.

${ }^{3}$ Sayuti Thalib, Hukum Kekeluargaan Indonesia, cet 5, Jakarta: UI- Press, 1986, Hlm 47.

${ }^{4}$ Tolib Setiady, Intisari HUkum Adat Indonesia (Dalam Kajian Kepustakaan) Cetakan ke-2, Bandung: Alfabeta, 2009, Hlm.225. 
Pengertian perkawinan menurut Pasal 1 Undang- Undang Perkawinan menyebutkan bahwa: "Perkawinan adalah ikatan lahir batin antara seorang pria dan seorang wanita sebagai suami istri dengan tujuan membentuk keluarga atau rumah tangga yang bahagia dan kekal berdasarkan Ketuhanan Yang Maha Esa”.

Berdasarkan beberapa pengertian diatas, perkawinan mengandung beberapa unsur sebagai berikut :

a. Terdapat ikatan lahir batin

b. Dilakukan seorang pria dengan seorang wanita

c. Bertujuan membentuk keluarga ( rumah tangga yang bahagia dan kekal)

d. Berdasarkan Ketuhanan Yang Maha Esa

\section{Akibat Perkawinan}

Adanya perkawinan akan menimbulkan akibat hukum bagi harta kekayaan maupun anak yang dilahirkan dalam perkawinan. Hal ini tercermin dalam Undang- Undang Perkawinan yang intinya menetapkan sebagai berikut :5

a. Akibat Perkawinan terhadap suami istri

Undang- Undang Perkawinan mengatur akibat- akibat hukum yang ditimbulkan dalan perkawinan terhadap suami istri yaitu :

Bagi suami dan istri akan timbul hak dan kewajiban diantara mereka berdua dan hubungan mereka dengan masyarakat luas, hal ini tertuang pada Pasal 30 sampai dengan Pasal 34 Undang- Undang Perkawinan.

Pasal 30 Undang- Undang Perkawinan menyebutkan bahwa, " suami istri memikul kewajiban yang luhur untuk menegakkan rumah tangga yang menjadi sendi dasar susunan masyarakat'.

Kewajiban suami istri sebagaimana disebutkan dalam Pasal 30 Undang- Undang Perkawinan tersebut lebih lanjut ditegaskan lagi dalam Pasal 33 Undang- undang Perkawinan, bahwa," suami istri wajib saling cinta- mencinta, hormat-menghormati, setia dan memberi bantuan lahir batin yang satu kepada yang lainnya".

Saling mencintai, saling menghormati, saling membantu lahir batin dan saling setia serta saling mmeberi diantara suami istri itu, maka terpenuhi kewajiban masing- masing dalam menegakkan rumah tangga mereka. Pengertian akan kewajiban saling mencintai dan saling membantu itu, jelas harus diakui oleh masing- masing suami istri, mereka telah menjadi satu kesatuan yang utuh dan masing- masing mengakui bahwa diantara mereka punya kelebihan dan kekurangan.

Pasal 31 ayat (1) Undang- Undang Perkawinan menyebutkan bahwa hak dan kedudukan istri adalah seimbang dengan hak dan kedudukan suami dalam rumah tangga dan pergaulan hidup masyarakat. Menurut Prof. Sardjono, maksudnya dari Pasal 31 ayat (1 ) ini bila dihubungkan dengan ketentuan- ketentuan dalam ayat 2-3, serta dalam Pasal 32,35,36,41, 45, dan 47 Undang- Undang Perkawinan saling memiliki keterikatan.

Secara garis besar dapat disimpulkan bahwasanya undang- undang memberikan wewenang tertentu kepada suami istri baik secara kolektif dasar individual. Hal tersebut dilakukan keduanya dalam rangka membina keluarga yang bahagia dan sejahtera atas

\footnotetext{
${ }^{5}$ Mulyadi, Hukum Perkawinan Indonesia, Fakultas Hukum Universitas Diponegoro, Semarang; 1992. Hlm 49.
} 
tanggung jawab dengan tetap menghindarkan pembagian atau pemisahan tugas antara suamiistri. $^{6}$

b. Akibat dari perkawinan yang berkaitan dengan harta benda.

Mengenai harta benda dalam perkawinan diatur dalam Pasal 35, 36, 37 Undang- Undang Perkawinan. Ketentuan mengenai harta benda perkawinan ini sangat dipengaruhi oleh hukum adat yang berlaku di Indonesia. Pengaruh dari ketentuan hukum agama, khususnya agama Islam tidak ada terhadap ketentuan harta benda perkawinan.

Undang- Undang Perkawinan, mengatur harta benda dalam perkawinan,yang terbagi sebagai berikut :

1.Harta Bersama

Menurut pasal 35 ayat (1) Undang- Undang perkawinan disebutkan bahwa harta benda yang diperoleh selama perkawinan menjadi harta bersama. Maksudnya adalah semua harta yang dibeli atau diperoleh selama perkawinan adalah harta bersama, walaupun harta tersebut diatas namakan salah seorang, baik suami maupun istri. Bahkan juga harta yang dibeli bersama dengan uang yang diperoleh selama perkawinan juga masuk harta bersama. Dengan demikian, dalam harta bersama kedudukan suami istri adalah sama dan seimbang. 2.Harta Bawaan

Menurut Pasal 35 ayat (2) Undang- Undang Perkawinan dijelaskan bahwa, harta bawaan dari masing- masing suami istri dan harta benda yang diperoleh masing- masing sebagai hadiah atau warisan, adalah di bawah penguasaan masing- masing sepanjang para pihak tidak menentukan lain. Mengenai harta bawaan, masing- masing suami dan istri mempunyai hak sepenuhnya untuk melakukan perbuatan hukum mengenai harta bendanya, sebagaimana disebutkan dalam Pasal 36 ayat (2) Undang- Undang Perkawinan.

\section{Prinsip- prinsip Perkawinan}

Asas (prinsip) merupakan suatu pernyataan fundamental atau kebenaran umum yang dapat dijadikan pedoman pemikiran dan tindakan. Asas- asas muncul dari hasil penelitian dan tindakan. Asas adalah dasar tapi bukan suatu yang absolut atau mutlak, artinya penerapan asas harus mempertimbangkan keadaan- keadaan khusus dan keadaan yang berubah- ubah. ${ }^{7}$

Prinsip-prinsip hukum perkawinan yang dituangkan dalam Undang- Undang Perkawinan dan Kompilasi Hukum Islam yang mengandung 7 asas kaidah hukum yaitu sebagai berikut ${ }^{8}$

a. asas membentuk keluarga yang bahagia dan kekal

b. asas keabsahan perkawinan didasarkan pada hukum agama dan kepercayaan bagi pihak yang melaksanakan perkawinan dan harus dicatat oleh petugas yang berwenang

c. asas monogami terbuka

d. asas calon suami dan istri yang telah matang jiwa raganya dapat melangsungkan perkawinan, agar mewujudkan tujuan perkawinan secara baik dan mendapat keturunan yang baik dan sehat sehingga tidak berfikir kepada perceraian

e. asas mempersulit terjadinya perceraian

${ }^{6}$ Sardjono H.R. Berbagai- bagai masalah Hukum dalam Undang- Undang Republik Indonesia No. 1 Tahun 1974. Naskah yang tidak pernah dipublikasikan, tetapi menjadi naskah wajib pada Fakultas Hukum Universitas Trisakti (1975- 1999)

${ }^{7}$ Malayu S.P Hasibuan, Manajemen: Dasar, Pengertian, dan Masalah, Jakarta: PT. Bumi Aksara, 2006, Hlm 9.

${ }^{8}$ Zainudin Ali, Hukum Perdata Islam Indonesia, Cetakan Pertama, Jakarta: Sinar Grafika, 2006, Hlm 7. 
f. asas keseimbangan hak dan kewajiban antara suami dan istri baik dalam kehidupan rumah tangga maupun kehidupan masyarakat

g. asas pencatatatan perkawinan, kompilasi hukum islam menekankan perkawinan dalam konsep hukum islam, namun tetap didasarkan pada Undang- Undang Perkawinan.

Adapun prinsip- prinsip atau asas- asas perkawinan yang dijelaskan dalam penejelasan umum Undang- Undang Perkawinan sebagai berikut :

a) Tujuan Perkawinan adalah membentuk keluarga yang bahagia dan kekal. Untuk itu suami istri perlu saling membantu dan melengkapi agar masing- masing dapat mengembangkan pribadinya, membantu dalam mencapai kesejahteraan spiritual dan material.

b) Undang- Undang Perkawinan menyatakan bahwa suatu perkawinan adalah sah bilamana dilakukan menurut hukum masing- masing agamanya dan kepercayaan itu, dan adisamping itu tiap- tiap perkawinan harus dicatat menurut peratutan perundang-undangan yang berlaku, pencatatan tiap- tiap perkawinan adalah sama halnya dengan pencatatan peristiwaperistiwa penting dalam kehidupan seseorang, misalnya kelahiran, kematian yang dinyatakan dalam surat- surat keterangan, suatu akte resmi yang juga dimuat dalam daftar pencatatan.

c) Undang- Undang ini menganut asas monogami, hanya apabila dikehendaki oleh yang bersangkutan mengijikannya, seorang suami dapat beristri lebih dari seoramg, namun demikian perkawinan seorang suami dengan lebih dari seorang istri, meskipun hal itu dikehendaki oleh pihak- pihak yang bersangkutan hanya dapat dilakukan apabila dipenuhi berbagai persyaratan tertentu dan diputuskan oleh Pengadilan Agama.

d) Undang- Undang ini mengatur prinsip, bahwa calon suami istri itu harus masak jiwa raganya untuk dapat melangsungkan perkawinan, agar supaya dapat mewujudkan tujuan perkawinan secara baik tanpa berakhir perceraian, dan mendapat keturunan yang baik dan sehat, untuk itu harus dicegah adanya perkawinan antara calon suami istri yang masih dibawah umur, karena perkawinan itu mempunyai hubungan dengan masalah kependudukan, maka untuk mengontrol lajunya kelahiran yang lebih tinggi, harus dicegah perkawinan antara calon suami istri yang masih dibawah umur, berhubungan dengan itu, maka Undang- Undang Perkawinan ini menentukan batas umur untuk kawin baik bagi pria maupun wanita, ialah 19 tahun untuk pria dan 16 tahun untuk wanita.

e) Tujuan perkawinan adalah untuk membentuk keluarga yang bahagia, kekal dan sejahtera, maka Undang- Undang ini menganut prinsip untuk mempersukar terjadinya perceraian. Untuk memungkinkan perceraian harus ada alasan-alasan tertentu, sebagaimana disebutkan dalam Pasal 19 Peraturan Pemerintah Nomor 9 tahun 1975 tentang penjelasan UndangUndang Perkawnan serta harus dilakukan di depan sidang Pengadilan Agama bagi orang Islam dan Pengadilan Negeri bagi golongan luar Islam.

f) Hak dan kedudukan istri adalah seimbang dengan hak dan kedudukan suami baik dalam kehidupan rumah tangga maupun dalam pergaulan bermasyarakat, sehingga segala sesuatu dalam keluarga dapat dirundingkan dan diputuskan bersama suami istri.

\section{Fungsi dan Tujuan Perkawinan}

\section{a. Fungsi Perkawinan}

Hubungan suami istri setelah perkawinan bukanlah merupakan hubungan perikatan yang berdasarkan perjanjian atau kontrak, akan tetapi ini merupakan suatu paguyuban, yaitu paguyuban hidup yang menjadi ajang pokok, ajang hidup suami istri selanjutnya bersama 
anak- anaknya. Paguyuban hidup tersebut lazim disebut somah ( istilah jawa yang berate keluarga) dalam somah itu, hubungan suami istri adalah sedemikian rapatnya sehingga dalam pandangan orang jawa mereka berdua itu merupakan ketunggalan. ${ }^{9}$

b. Tujuan perkawinan

Pada dasarnya tujuan perkawinan adalah untuk memperoleh keturunan yang sah dalam masyarakat, dengan mendirikan sebuah kehidupan rumah tangga yang damai dan tentram. ${ }^{10}$

\section{Syarat- syarat sahnya Perkawinan}

Suatu perkawinan baru dapat dikatakan sah apabila memenuhi syarat- syarat perkawinan dan dilakukan menurut hukum masing- masing agama serta dicatat menurut peraturan perundang-undangan. Syarat- syarat perkawinan diatur dalam Undang- Undang Perkawinan adalah syarat materiil dan formil sebagai berikut $:^{11}$

a. Syarat- syarat materiil secara umum

1) Harus ada persetujuan dari kedua belah pihak calon mempelai.

2) Usia calon mempelai pria sekurang- kurangnya harus mencapai 19 tahun dan pihak calom mempelai wanita harus sudah berumur 16 tahun.

3) Tidak terikat tali perkawinan dengan orang lain.

4) Syarat materiil secara khusus, yaitu :

a) Tidak melanggar larangan perkawinan yang diatur Undang- Undang Perkawinan Pasal 8, Pasal 9, dan Pasal 10.

b) Izin kedua orangtua bagi calon mempelai yang belum berumur 21 tahun, yang berhak memberi izin kawin yaitu

i. Orangtua dari kedua belah pihak calon mempelai. Jika kedua orangtua masih ada, makai zin diberi bersama oleh kedua orangtua calon mempelai. Jika orangtua laki- laki telah meninggal dunia, pemberian izin perkawinan beralih kepada orang tua perempuan yang bertindak sebagai wali. Jika orangtua perempuan sebagai wali, maka halini bertentangan dengan perkawinan yang diatur Hukum Islam karena menurut Hukum Islam tidak boleh orangtua perempuan bertindak sebagai wali.

ii. Apabila salah seorang dari kedua orang tua telah meninggal dunia atau dalam keadaan tidak mampu menyatakan kehendaknya disebabkan karena berada di bawah kuratele, berada dalam keadaan tidak waras, dan tempat tingglnya tidak diketahui, maka izin cukup diberikan oleh orangtua yang masih hidup atau dari orantua yang mampu menyatakan kehendaknya.

iii. Apabila kedua orangtua telah meninggal dunia atau kedua- duanya dalam keadaan tidak bisa menyatakan kehendaknya maka izin diperoleh dari wali yang memelihara calon mempelai, keluarga yang mempunyai hubungan darah dalam garis keturunan ke atas selama masih hidup dan dalam keadaan dapat menyatakan kehendaknya.

\footnotetext{
9 Tolib Setiady, Intisari Hukum Adat Indonesia (Dalam Kajian Kepustakaan) Cetakan ke 2, Bandung: Alfabeta, 2009, Hlm 226.

${ }^{10}$ Ibid, hlm 226

${ }^{11}$ Asmin, Status Perkawinan Antar Agama Ditinjau dari Undang- Undang Nomor 1 Tahun 1974, Jakarta: PT. Dian Rakyat, 1986, Hlm 22- 24.
} 
iv. Jika ada perbedaan pendapat antara orang- orang yang disebut dalam Undang- Undang Perkawinan Pasal 6 ayat (2), (3), dan (4) atau seseorang atau lebih diantara orang- orang tidak ada menyatakan pendapatnya, pengadilan dalam daerah hukum tempat tinggal orang yang hendak melangsungkan perkawinan bertindak memberi izin perkawinan. Pemberian izin dari pengadilan diberikan atas permintaan pihak yang hendak melakukan perkawinan, setelah lebih dulu pengadilan mendengar sendiri orang yang disebut dalam UndangUndang Perkawinan Pasal 6 ayat (2), (3), dan (4).

b. Syarat- syarat formil

a. Pemberitahuan kehendak akan melangsungkan perkawinan kepada pegawai pencatat perkawinan.

b. Pengumuman oleh pegawai pencatat perkawinan.

c. Pelaksanaan perkawinan menurut hukum agama dan kepercayaan masing- masing.

d. Pencatatatan perkawinan oleh pegawai pencatat perkawinan.

\section{Tinjauan Batasan Umur Melakukan Perkawinan}

2.2.1..Batasan Umur Melakukan Perkawinan Menurut Undang- Undang Nomor 1 Tahun 1974

Pasal 6 Kompilasi Hukum Islam (KHI) menyatakan bahwa untuk melangsungkan perkawinan seseorang yang belum mencapai umur 21 tahun harus mendapat ijin dari orangtuanya. Namun demikian prakteknya di dalam masyarakat ini masih banyak dijumpai sebagian masyarakat yang melangsungkan perkawinan di usia dini.

Dispensasi merupakan penetapan pengadilan, mengenai pembolehan perkawinan yang dilakukan oleh pasangan pengantin yang salah satunya atau keduanya belum berumur 19 (Sembilan belas) tahun bagi laki- laki dan 16 (enam belas ) tahun bagi perempuan. ${ }^{12}$

\subsubsection{Batasan Umur Melakukan Perkawinan Menurut Kompilasi Hukum Islam}

Mengenai Batasan umur untuk melakukan perkawinan menurut Kompilasi Hukum Islam menerangkan bahwa calon mempelai yang hendak melakukan perkawinan apabila calon mempelai yang belum mencapai 21 tahun maka calon mempelai mendapat izin sebagai mana diatur dalam Pasal 6 ayat (2). (3), (4), dan (5) Undang- Undang Nomor 1 tahun 1974.

\subsubsection{Menurut Reproduksi}

Menurut ilmu kesehatan pasangan yang ideal adalah dari segi umur sudah matang yaitu minimal 20 tahun. Umur yang sudah tertera itu pada umumnya sudah merupakan masa yang paling baik untuk menjalin suatu ikatan tali rumah tangga. Karena pada usia tersebut telah cukup dikatakan matang dan sudah dewasa. Dalam hal ini dewasa yang dimaksud adalah sudah mampu untuk cara bertindak dan matang cara berpikirnya. ${ }^{13}$

\subsubsection{Menurut Para Ahli Hukum Islam}

a. Pandangan jumhur fuqaha ( ahli fiqih)

\footnotetext{
${ }^{12}$ R. Subekti dan R. Tjitrosoedibio, Kamus Hukum, Jakarta: PT. Pradnya Paramitha, 1996, hlm.36-37. ${ }^{13}$ www.http// Persiapan Perkawinan. Ditinjau.Dari. Segi. Biologis, dan Psikologis. Html (08-04-2019/20.20 WIB)
} 
Pandangan jumhur fuqaha ( ahli fiqih) yang memperbolehkan perkawinan di bawah umur serta merta membolehkan adanya hubungan badan. Jika berhubungan badan akan mengakibatkan adanya dharar ( bahaya), maka hal itu dilarang, baik perkawinan di bawah umur maupun dewasa. ${ }^{14}$

b. Pandangan Ibnu Syubrumah dan Abu Bakr Al -Asham

Pandangannya menyatakan bahwa perkawinan di bawah umur hukumnya terlarang mutlak

Nilai essensial pernikahan adalah memenuhi kebutuhan biologis dan melanggengkan keturunan. Sementara dua hal ini tidak terdapat pada anak yang belum baligh. Ia lebih menekankan pada tujuan pokok pernikahan. ${ }^{15}$

c. Pandangan Ibn Hazm

Memilah antara perkawinan anak lelaki kecil dan anak perempuan kecil. Jika perkawinan anak perempuan kecil oleh bapaknya diperbolehkan, sedangkan perkawinan anak lelaki kecil dilarang. Argumen yang dijadikan landasan adalah zhahir hadist perkawinan ${ }^{16}$.

d. Pandangan Syekh Ibrahim

Bahwa agar jalur nasab tetap terjaga, hubungan seks yang mendapatkan legalitas agama harus melalui suatu ikatan pernikahan. Seandainya agama tidak mensyariatkan pernikahan, niscaya genealogi ( jalur keturunan) akan semakin kabur ${ }^{17}$.

\section{Dispensasi Perkawinan}

Perkawinan di bawah umur dapat dilakukan dengan cara memohon dispensasi. Seepeprti yang tertuang dalam Pasal 7 ayat (2) UU Perkawinan, yang menyatakan dalam hal penyimpangan terhadap ayat (1) pasal ini dapat meminta dispensasi kepada Pengadilan atau Pejabat lain yang ditunjuk oleh kedua orang tua pihak pria maupun wanita. ${ }^{18}$

UU Perkawinan telah mengatur batas usia perkawinan, namun dalam pasal lainnya terdapat pengecualian, artinya perkawinan dapat dilaksanakan apabila terdapat dispensasi dari pengadilan.

Dispensasi berupa izin sebagai dasar bagi Kantor Urusan Agama (KUA) atau Catatan Sipil untuk menikahkan calon pasangan suami istri.. Dispensasi diajukan dalam bentuk permohonan.

Mengacu pada Pasal 49 dan 50 Undang Undang Peradilan Agama, maka yang memiliki kompetensi absolut untuk menerima dan memutus serta menetapkan permohonan dispensasi adalah Pengadilan Agama bagi para pihak yang beragama Islam dan Pengadilan Negeri bagi yang beragama selain Islam.

Untuk menerapkan kewenangan absolut Pengadilan Agama dalam hal dispensasi kawin, berpedoman pada hukum acara yang berlaku pada pengadilan umum, kecuali yang telah diatur secara khusus dalam Undang undang Peradilan Agama, dan dengan kehadiran Kompilasi Hukum Islam yang memuat himpunan kaidah- kaidah hukum Islam yang disusun secara

\footnotetext{
${ }^{14}$ Sonny Dewi Judiasih dkk, Perkawinan Bawah Umur di Indonesia Beserta Perbandingan Usia Perkawinan dan Praktik Perkawinan bawah Umur di Beberapa Negara., Bandung,PT. Refika Aditama,2018, Hlm 18

15 Ibid. Hlm 19

${ }^{16}$ Ibid

${ }^{17}$ Ibrahim, Al Bajuri, Vol 2, Semarang, Toha Putra 2000, Hlm 90

${ }^{18}$ Sonny Dewi Judiasih, Op.Cit, Hlm 37.
} 
sistematik sebagai hukum terapan, dikenal dengan istilah fiqih Indonesia. ${ }^{19}$ Kompilasi Hukum Islam, salah satu sumber hukum Islam bagi masyarakat muslim Indonesia menjadi pedoman hukum materil dan formil bagi Pengadilan Agama dalam mengadili dan menyelesaikan perkara dispensasi kawin, sementara di Pengadilan Negeri berlaku ketentuan HIR/RBg.

\section{PEMBAHASAN}

\section{Pelaksanaan perkawinan di bawah umur di Kecamatan Lengkong pasca putusan Mahkamah Konstitusi.}

Bahwa angka permohonan dispensasi untuk melaksanakan perkawinan di bawah umur di Kota Bandung terus meningkat. Hal ini merupakan fenomena dan fakta yang harus disikapi bersama khususnya bagi pemerintah, masyarakat dan keluarga.

Telah terjadi pergeseran tren perkawinan di bawah umur, yang biasa terjadi di pinggiran kota, kini merambah ke perkotaan. Perkawinan di bawah umur di kota besar disebabkan anak muda yang tidak bisa memilah dan memilih pergaulan di lingkungannya, serta perkawinan di bawah umur juga merupakan salah satu faktor penyebab terjadinya kekerasan terhadap anak karena orang tua nya belum siap menjadi orang tua karena belum matang, belum mampu dari segi ekonomi serta sosial, bahkan yang terpenting adalah mereka belum mampu dalam mengasuh anak.

Putusan Mahkamah Konstitusi yang menyatakan bahwa Pasal 7 ayat (1) UU Perkawinan yang mengatur batas minimal perkawinan laki- laki adalah 19 tahun dan perempuan adalah 16 tahun bertentangan dengan UUD 1945 ( Pasal 28 A, 28 B, 28 C, 28 D, 28 G, 28 H, 28 I) dan UU Perlindungan Anak

UU Perlindungan Anak menyebutkan bahwa anak- anak adalah mereka yang berusia di bawah 18 tahun, sehingga batas usia yang diatur dalam UU Perkawinan masih kategori anak..

Setelah adanya putusan Mahkamah Konstitusi tersebut, khusus di wilayah Kecamatan Lengkong dalam Tahun 2019 tidak terjadi perkawinan di bawah umur, hal ini ditegaskan oleh Kepala Kantor Urusan Agama (KUA). Hal ini disebabkan penduduk wilayah ini sebagian besar berpendidikan tinggi sehingga kaum muda setelah lulus pendidikan sarjana mereka berusaha untuk mengejar karir terlebih dahulu baik laki-laki maupun perempuan, agar secara ekonomi mapan dan secara sosial meningkat kedudukannya. Orang tua pun besar pengaruhnya terhadap anaknya yang tidak menghendaki anaknya menikah sebelum mereka mendapatkan pekerjaan dan hidup mapan.

\section{Faktor Penyebab Terjadinya Perkawinan di Bawah Umur}

Beberapa faktor yang mempengaruhi permohonan dispensasi ke Pengadilan Agama, dapat dilihat dari segi sosiologis dan yuridis.

Faktor sosiologis yaitu adanya kekhawatiran terhadap pemohon dispensasi dengan terjadinya perbuatan yang dilarang oleh agama jika tidak segera dinikahkan, pemohon sudah siap untuk membina rumah tangga. Sedangkan dari faktor yuridis adalah bahwa dispensasi harus diajukan permohonan kepada Pengadilan Agama berdasarkan alasan- alasan berdasarkan Pasal 7 UU Perkawinan.

Adapun faktor faktor yang menjadi alasan pengajuan dispensasi itu adalah antara lain :

1. Kehendak nikah ditolak oleh Kantor Urusan Agama

\footnotetext{
${ }^{19}$ Ibid. Hlm 39.
} 
2. Telah berhubungan cukup lama

3. Keduanya saling mencintai dan sulit dipisahkan

4. Calon suami sudah mampu bertanggung jawab

5. Calon mempelai wanita sudah hamil

6. Keduanya tidak ada halangan hukum untuk menikah

7. Bila tidak segera dinikahkan akan terjadi hal-hal yang tidak diinginkan

8. Berpacaran cukup lama dan setuju untuk menikah.

Berdasarkan alasan- alasan yang biasa digunakan dalam permohonan dispensasi tersebut,tidak tampak secara transparan alasan ekonomi, padahal banyak orang tua yang menghendaki anaknya menikah di bawah umur untuk melepaskan beban ekonomi. Namun hasilnya justru sebaliknya.

Banyaknya perkawinan di bawah umur berbanding lurus dengan tingginya angka perceraian , yang disebabkan antara lain ego anak yang masih tinggi, perselingkuhan, ketidak cocokan hubungan dengan orang tua maupun mertua, psikologis yang belum matang sehingga cenderung labil secara emosional, serta tidak atau kurang mampu bersosialisasi dan beradaptasi dengan sua,i/ istri dan keluarga besar.Akhirnya si anak dan cucu kembali menjadi beban orang tua yang berakibat pada kemiskinan keluarga tersebut.

Perkawinan di bawah umur dalam prakteknya tidak dapat dilepaskan dari kondisi ekonomi, sosial, budaya serta agama yang berkembang dalam masyarakat .Permasalahan tentang usia perkawinan selalu menimbulkan berbagai penafsiran, khususnya bagi seorang wanita adalah adanya kehamilan dalam usia terlalu dini yang dapat menimbulkan resiko, antara lain :

a. Potensi mengalami kesulitan dan kerentanan saat hamil serta melahirkan anak premature karena belum matangnya pertumbuhan phisik.;

b. Cenderung melahirkan anak yang kurang gizi atau bayi cacat;

c. Ibu beresiko anemia, eklapsi dan mudah terjadi pendarahan pada proses persalinan;

d. Angka depresi ibu meningkat, bahkan angka kematian ibu karena perkembangan psikologis belum stabil;

e. Rentan terhadap kanker serviks karena berhubungn badan di bawah usia 15 tahun

f. Kekerasan dalam rumah tangga.

Bahwa faktor penyebab terjadinya perkawinan di bawah umur adalah kemiskinan/ ekonomi, pendidikan rendah, sosial, budaya, dan agama.

\section{Upaya Pemerintah Dalam Menanggulangi Perkawinan Di Bawah Umur}

Salah satu upaya untuk menekan kenaikan perkawinan di bawah umur, maka Badan Koordinasi Keluarga Berencana Nasional (BKKBN) bekerja sama dengan Komisi IX DPR telah melaksanakan Program Generasi Berencana (Genre) Ceria.

Sasaran program Genre Ceria adalah remaja dan ibu rumah tangga, bertujuan untuk mencegah generasi milenial terjerumus kepada prilaku negatif, seperti seks bebas,dan penyalahgunaan narkotika, psikotropika dan zat adiktif (Napza).

Upaya dan langkah yang dilakukan pemerintah untuk menekan atau menghentikan perkawinan di bawah umur adalah dengan memperkuat program-program pendidikan anak perempuan bersekolah dan belajar agar orang tua mereka melakukan pertimbangan untuk menunda pernikahan mereka. Pendidikan merupakan satu- satunya faktor yang paling penting 
menentukan apakah seorang anak perempuan akan menikah sebelum usia mereka mencapai 18 tahun atau setelahnya.

Instruksi Presiden Nomor 1 Tahun1991 tentang Kompilasi Hukum Islam (KHI), dalam Pasal 15 menyebutkan bahwa batas usia perkawinan sama seperti Pasal 7 UU Perkawinan, namun dengan tambahan alasan untuk kemaslahatan keluarga dan rumah tangga.

KHI pun menyebutkan perkawinan dapat dibatalkan antara lain bila melanggar batas umur perkawinan sebagaimana ditetapkan dalam Pasal 7 UU Perkawinan. Para pihak yang dapat mengajukan permohonan pembatalan perkawinan adalah :

1) Para keluarga dalam garis keturunan lurus ke atas dan ke bawah oleh suami atau istri

2) Suami atau istri

3) Pejabat yang berwenang mengawasi pelaksanaan perkawinan menurut undang-undang

4) Para pihak berkepentingan yang mengetahui adanya cacat dalam rukun dan syarat perkawinan menurut hukum Islam dan peraturan perundang- undangan.

Undang undang Nomor 35 Tahun 2014 sebagaimana diubah dari Undang undang Nomor 23 Tahun 2002 tentang Perlindungan Anak sebagai instrument Hak Asasi Manusia, juga tidak meyebutkan secara eksplisit tentang usia minimum menikah selain menegaskan bahwa anak adalah mereka yang berusia di bawah 18 tahun, Disebutkan pula bahwa penyelenggaraan perlindungan anakberasaskan Pancasila dan berlandaskan Undang Undang Dasar Negara Republik Indonesia Tahun 1945 serta prinsip- prinsip dasar Konvensi Hak Hak Anak, meliputi :

a) Non diskriminasi

b) Kepentingan yang terbaik bagi anak

c) Hak untuk hidup, kelangsungan hidup dan perkembangan

d) Penghargaan terhadap pendapat anak.

Perlindungan anak bertujuan untuk menjamin terpenuhinya hak- hak anak agar dapat hidup, tumbuh, berkembang dan berpartisipasi secara optimal sesuai dengan harkat dan martabat kemanusiaan, serta mendapat perlindungan dari kekerasan dan diskriminasi demi terwujudnya anak Indonesia yang berkualitas, berakhlak mulia dan sejahtera. Pasal 2 (1) huruf (c) UU Perlindungan Anak menyebutkan bahwa orang tua berkewajiban dan bertanggung jawab untuk mencegah terjadinya perkawinan pada usia anak- anak.

Menyikapi Putusan Mahkamah Konstitusi 2018, Dewan Pemerintah telah mengesahkan Undang Undang Nomor 16 Tahun 2019 tentang Perubahan Atas Undang Undang Nomor 1 Tahun 1974. Ditetapkan pada tanggal 14 Oktober 2019 dan berlaku sejak 15 Oktober 2019.

UU Perkawinan yang baru mengubah batas minimal menikah laki- laki dan perempuan yang akan menikah minimal di usia 19 tahun. Terbitnya UU Perkawinan yang baru, akan diikuti dengan penyusunan kebijakan nasional pencegahan perkawinan di bawah umur, antara lain dengan melakukan kampanye stop perkawinan di bawah umur dan perkawinan di bawah umur harus dicegah mulai tingkat desa.

Untuk tataran Mahkamah Agung ( MA), saat ini tengah mempersiapkan aturan pemberian dispensasi untuk mengidentifikasi ada atau tidak adanya paksaan dalam pengajuan dispensasi perkawinan anak. MA pun meminta para hakim mempertimbangkan perlindungan dan kepentingan terbaik bagi anak. Tugas hakim ialah menasehati pemohon, anak, calon suami/istri dan orang tua/ wali calon suami/ istri tentang akibat perkawinan anak. 
Pemerintah telah berupaya untuk menekan kenaikan angka perkawinan di bawah umur, agar menghasilkan generasi yang berkualitas dam menyongsong globalitas dunia.

\section{PENUTUP}

\section{Kesimpulan}

1. Bahwa pelaksanaan perkawinan di bawah umur di wilayah Kecamatan Lengkong Kota Bandung pada sepanjang Tahun 2019 tidak ada , meskipun pengajuan dispensasi untuk menikah di Kota Bandung masih tinggi. Tidak adanya perkawinan di bawah umur di wilayah ini karena sebagian besar penduduknya berpendidikan tinggi dan generasi mudanya lebih mengutamakan karir terlebih dahulu agar berkehidupan social dan ekonominya mapan.

2. Bahwa faktor- faktor penyebab terjadinya perkawinan di bawah umur adalah kemiskinan/ ekonomi, rendahnya pendidikan, sosial, budaya dan agama.

3. Bahwa upaya yang dilakukan oleh pemerintah untuk menekan kenaikan angka perkawinan di bawah umur adalah dengan membentuk program- program pendidikan untuk perempuan, membuat program Generasi Berencana (Genre) Ceria, merubah UU Perkawinan yang mengatur batas usia minimum untuk menikah laki- laki dan perempuan menjadi 19 tahun serta melakukan kampanye stop perkawinan di bawah umum mulai dari pedesaan.

\section{Saran}

1. Bahwa untuk meminimalisir perkawinan di bawah umur merupakan kewajiban segenap bangsa, maka pemerintah dengan masyarakat harus terus mensosialisasikan stop perkawinan di bawah umur.

2. Program wajib belajar 12 tahun ditingkatkan agar menghasilkan generasi yang unggul

3. Perekonomian masyarakat ditingkatkan dengan bantuan modal dari pemerintah/ swasta agar masyarakat dapat mengembangkan kewirausahaan di berbagai bidang.

\section{DAFTAR PUSTAKA}

\section{A Buku :}

Asmin, Status Perkawinan Antar Agama Ditinjau dari Undang- Undang Nomor 1 Tahun 1974, Jakarta: PT. Dian Rakyat, 1986.

Ibrahim, Al Bajuri, 2., Semarang, Toha Putra, 2000

Malayu S.P Hasibuan, Manajemen: Dasar, Pengertian, dan Masalah, Jakarta: PT. Bumi Aksara, 2006.

Mulyadi, Hukum Perkawinan Indonesia, Fakultas Hukum Universitas Diponegoro, Semarang; 1992.

R. Subekti dan R. Tjitrosoedibio, Kamus Hukum, Jakarta: PT. Pradnya Paramitha, 1996.

Sayuti Thalib, Hukum Kekeluargaan Indonesia, cet 5, Jakarta: UI- Press, 1986.

Sonny Dewi Judiasih dkk, Perkawinan Bawah Umur di Indonesia. Beserta Perbandingan Usia Perkawinan dan Praktik Perkawinan Bawah Umur di Beberapa Negara, Bandung, PT. Refika Aditama,2018. 
Tihami dan Sohari Sahrani, Fiqh Munakahat: Kajian Fiqh Lengkap, Jakarta : Rajawali Press, 2009 ,

Tolib Setiady, Intisari Hukum Adat Indonesia (Dalam Kajian Kepustakaan) Cetakan ke-2, Bandung: Alfabeta, 2009,

Zainudin Ali, Hukum Perdata Islam di Indonesia, Jakarta, Sinar Grafika,2007,

Peraturan perundang- undangan

Undang- Undang Dasar 1945

Undang- Undang Nomor 1 Tahun 1974 Tentang Perkawinan

Undang Undang Nomor 3 Tahun 2006 Tentang Perubahan Atas Undang Undang Nomor 7

Tahun 1989 Tentang Peradilan Agama

Undang Undang Nomor 35 Tahun 2014 tentang Perlindungan Anak

Undang Undang Nomor 16 Tahun 2019 Tentang Perubahan Atas Undang Undang Nomor 1 Tahun 1974 tentang Perkawinan

Instruksi Presiden Nomor 1 Tahun 1991 Tentang Kompilasi Hukum Islam

A. Sumber lain

www.http// Persiapan Perkawinan. Ditinjau.Dari. Segi. Biologis, dan Psikologis. Html (08-042019/20.20 WIB) 